\title{
THE FORMULATION OF DRY CURCUMA (CURCUMA XANTHORRHIZA ROXB.) EXTRACT MICROCAPSULES BY SPRAY WET MICROENCAPSULATION TECHNIQUES
}

\author{
SAMRAN SAMRAN*, DALIMUNTHE, GI \\ Department of Pharmacy, Faculty of Mathematics and Natural Science, University of Muslim Nusantara Al-Washliyah, Jl. Gaharu II No.2, \\ Medan Amplas, Medan 20147, Indonesia. Email: Samranamatrejo@gmail.com
}

Received: 16 September 2017, Revised and Accepted: 06 December 2017

\section{ABSTRACT}

Objective: Curcuma xanthorrhiza Roxb. was used as hereditary medicinal plant for prevention of liver dysfunction, gastrointestinal disease, fever, and hemorrhoid. Curcuma extract was easy to damage because the light exposure, change of pH, weather and a long period of storage time. The problem can be solved by coating the extract with spray wet microencapsulation (SWM) technique. SWM technique is a method of preparing microcapsules in which a solution, suspension, or emulsion with a charged matrix is sprayed into opposing solution. The aim of this research was to formulate the dry Curcuma extract with SWM technique using sodium alginate as matrix.

Methods: Brown algae (Sargassum ilicifolium) was a main resource of alginate acid. It was isolated using $\mathrm{HCl} 5 \%$ to make alginate acid and sodium alginate that was obtained by adding $\mathrm{Na}_{2} \mathrm{CO}_{3} 5 \%$ to alginate acid solution. The microencapsulation process of Curcuma extract was done by SWM technique. The formula of Curcuma extract microencapsulation was design into three formulas: F1, F2, and F3. Microcapsules of Curcuma extract were being characterized for color intensity, analysis of scanning electron microscope (SEM), compressibility index, flowing time, and determination of angle repose.

Results: The results showed that the higher concentration of sodium alginate used, the dry Curcuma extract microcapsules produced better. Particle size of extract microcapsules of Curcuma extract microcapsules SEM from F1, F2, F3 was $20 \mu$ mhereas dry weight of extracted microcapsule of Curcuma grows with increasing concentration of sodium alginate: F1 (0.2\%) 19.86 $\pm 0.11 \mathrm{~g}, \mathrm{~F} 2(0.4 \%) 20.66 \pm 0.73$, F3 (0.6\%) 21.29 \pm 0.64 . The flowing time of F1, F2, and F3 was $6.92 \pm 0.56,7.42 \pm 0.50$, and $8.05 \pm 0.54$ s consecutively.

Conclusions: Based on the analysis of the study result, it can be concluded that the raw materials of Curcuma extract can be made by SWM technique using sodium alginate isolated from brown algae, and the characterization of dry Curcuma extract microcapsule of the three formulas met the requirements of the pre-formulation tests for capsule dosage form.

Keywords: Microencapsulation, Spray wet microencapsulation techniques, Dry Curcuma extract.

(C) 2018 The Authors. Published by Innovare Academic Sciences Pvt Ltd. This is an open access article under the CC BY license (http://creativecommons. org/licenses/by/4. 0/) DOI: http://dx.doi.org/10.22159/ajpcr.2018.v11i3.22608

\section{INTRODUCTION}

Brown algae (Sargassum ilicifolium) is one of the source of raw material in producing alginate that widely used and available in Indonesia, especially North Sumatra [1]. Brown algae have xantofil pigment that gives the brown color and can produce algin or alginic. The concentration of alginate in brown algae was dependent on the season, growing, harvesting, and types of algae [2]. Sodium alginate is the final product of alginate extraction process. Sodium alginate is widely used in the pharmaceutical field as a suspending agent, thickening agent, stabilizer oil in water emulsion, and as a binder and a disintegrator of a tablet formulation [3].

Curcuma xanthorrhiza Roxb. has been used as the hereditary medicinal plant for preventive dysfunction of liver, gastrointestinal disease, fever and haemorrhage. Curcumin has pharmacological effect as antioxidants, increasing appetite, anti-inflammatory, antihiperlipidemic, anticancer, antibacteria, dysfunction of hepar, dysfunction of renal, and antirheumatic [4]. Sodium alginate is water soluble and thickens to form a stable solution and has a possibility to use it in the microencapsulation process of Curcuma extracts, thus protecting the active ingredients of the condition of decay or the evaporation of the active component. Furthermore, because of the active ingredient protected by a matrix system (microcapsules material), this condition was able to prevent the decline in food or drug quality such as discoloration, an unwanted condition of the product [5]. The microencapsulation process also prevents the deactivation of the drug during the delivery process due to the protection by the polymer shell, and this ensures sufficient amount of drug in reaching the intended area [6].

Based on this, the researchers were interested in isolating the sodium alginates from brown algae (S. ilicifolium) and use it to make a dry extracts of Curcuma microcapsules using spray wet microencapsulation (SWM) technique with the aim to covering the taste and smell of Curcuma which is bitter so that it can improve patient compliance in taking the herbal drug $[7,8]$. The researcher developed SWM to overcome the obstacle of the drip method in a microencapsulation process that was not so applicable for industrial scale. SWM is an instrument that is designed for making microcapsules by applying chelate complex reaction between sodium alginate and calcium chloride.

\section{MATERIALS AND METHODS}

\section{Materials}

The ingredients used in this research include sodium alginates isolated from brown algae (S. ilicifolium) and Curcuma extract (C. xanthorrhizae L. Miers). The chemicals used are hydrochloric acid, sodium carbonate, hydrogen peroxide, sodium hypochlorite, calcium chloride and $\mathrm{CO}_{2}$-free distilled water, and ethanol $70 \%$. The tools used in this study are the glass tools laboratory (Pyrex), Blender (National), oven (Memmert), furnace (Thermolyne), viscometer (Myr), balance (Vibra ht), $\mathrm{pH}$ meter, flannel strainer, rotary evaporator (Schimadzu), SWM (Modification) tools. 


\section{Methods}

\section{Preparation of Curcuma extract}

$2000 \mathrm{~g}$ of Curcuma powder was macerated with $15.000 \mathrm{~mL}$ ethanol $70 \%$ in the closed chamber for 5 days and covered from the sunlight and stirred once a day. The solution resulted from the maceration was strained with flannel strainer (macerate I), and the waste substances were macerated again with $5 \mathrm{~L}$ ethanol $70 \%$ for 2 days. The second maceration process was done with similar methods with the first process until the second maceration result (macerate II) was obtained. The macerate I and II were combined and evaporated with rotary evaporator apparatus until the viscous Curcuma extract (evaporated to one-third) was obtained [9].

\section{Microencapsulation process by SWM technique}

Microencapsulation is a dosage form technology that can release their contents at controlled rates under specific conditions [10]. The raw material of Curcuma extract microcapsules was formulated using variation of sodium alginate concentrations and corn starch as a filler. Sodium alginate used in this study was obtained from the isolation of a brown alga (S. ilicifolium) taken from the coast of Sibolga, North Tapanuli. The formula of raw material of Curcuma extract microcapsules is shown in Table 1.

Sodium alginate weighted as much as $2.0 \mathrm{~g}(0.2 \%), 4.0 \mathrm{~g}(0.4 \%)$, $6.0 \mathrm{~g}(0.6 \%)$ then put in a $1000 \mathrm{ml}$ glass beaker, add $500 \mathrm{ml}$ of distilled water then stirred until swell completely. The viscous Curcuma extract and cornstarch dispersed into a solution of sodium alginate then stirred until homogeneous. The distilled water then added until the limit mark $1000 \mathrm{ml}$.

SWM is a technique that was designed to formulate microcapsules by the complex reactions between sodium alginate and $\mathrm{CaCl}_{2}$. The suspense solution in sodium alginate is sprayed in the form of mist or very small particle size using a spray gun with a pressure of $2-3$ bar. The fog particles react spontaneously with calcium chloride to form micro hydrogel. Micro hydrogel is then dried in the oven at a temperature of $50-60^{\circ} \mathrm{C}$ until dry $( \pm 8 \mathrm{~h})$ and forms the xerogel microcapsule alginate. This method makes it possible to overcome the problems in the method of drops to formulate microcapsules that can only be applied in the laboratory scale because of the small production capacity, needs longer time, and the size of the particles are still large.

Once homogeneous, the suspension of extract Curcuma in sodium alginate was sprayed using SWM tool into a solution of $0.15 \mathrm{M} \mathrm{CaCl}_{2}$ to form a gel. The formed gel was allowed for 15 minutes in the solution of $0.15 \mathrm{M} \mathrm{CaCl}_{2}$ then filtered and pressed and the gel dried in an oven at a temperature of $50^{\circ} \mathrm{C}$ for $8 \mathrm{~h}$ until dry.The dried gel then granulated and filtered with mesh 30 . The xerogel alginate gel in the form of microcapsules was then evaluated [11] and ready for used as raw materials for capsule dosage form.

\section{Granules characterization}

\section{Angle of repose}

The determination of angle of repose was done by using a funnel flow that has been assembled. The granules was added into the funnel; the surface was flattened, then opened the bottom cover of funnel and the granules allowed to flow through the funnel $[12,13]$. The angle of repose determined by the following formula:

Tangen $\theta=2 \mathrm{~h} / \mathrm{D}$

Note:

$\theta=$ Angle of repose

$\mathrm{h}=$ The high of cone $(\mathrm{cm})$

$\mathrm{D}=$ diameter $(\mathrm{cm})$

Requirement: $20^{\circ}<\infty<40^{\circ}$

\section{Flowing time}

The determination of flowing time was done using a funnel flow. The granules were added into a funnel that has been assembled then the granule surface leveled. Then, the bottom cover of funnel was opened, and stopwatch turned on simultaneously. The stopwatch stopped when all the granules have gone past the funnel and the flowing time required by granules recorded $[12,13]$.

The requirements: $\mathrm{T}_{\text {flow }}<10$ detik

\section{Compressibility indexes}

$50 \mathrm{ml}$ (V1) of granules were added into the compressibility index apparatus; then, press the "on" button at the apparatus. The apparatus was operated until the constant volume obtained (V2) $[12,13]$.

$$
\text { Compressibility index }(\mathrm{I})=\frac{\mathrm{v}_{1}-\mathrm{v}_{2}}{\mathrm{v}_{1}} \times 100 \%
$$

Requirement: $I \leq 20 \%$

\section{Organoleptic test of xerogel}

The organoleptic test of xerogel taste was done by hedonic test of 10 panelists. The numerical scale was used in the flavor determination test [14].

\section{RESULTS AND DISCUSSION}

\section{Curcuma extract microencapsulation}

The Curcuma extract microencapsulation process by sodium alginate was done by SWM technique. The result of microencapsulation process was shown in Table 2.

Sodium alginate can be used as a thickener, suspending agent, stabilizer, and gel, so when a suspension of Curcuma extract in sodium alginate was sprayed into a solution of calcium chloride, there will be an exchange between the calcium ions with sodium ions and form a gel.

The gel produced in this study was a type of water-containing gel (hydrogel) and lost liquid gel (xerogel). The extract Curcuma suspension in sodium alginate sprayed into a solution of calcium chloride that will be formed hydrogel directly. In the encapsulation procedure, the hydrogel was taken after allowed it for $15 \mathrm{~min}$ in the calcium chloride solution so that all the sodium alginate reacts with calcium ions, and after hydrogel dry, it will form a smaller form of xerogel [15].

Microencapsulation process by SWM technique was modification of drips method. The gel was sprayed and formed after the sodium alginate suspension sprayed into the $\mathrm{CaCl}_{2}$ It was because the cross-binding of carboxylate anion $\left(\mathrm{COO}^{-}\right)$from alginate monomer and divalen kation $\left(\mathrm{Ca}^{+}\right)[16]$

Table 1: The formula of microcapsules of Curcuma extract

\begin{tabular}{lllll}
\hline \multirow{2}{*}{ No. } & Composition & Formula & & \\
\cline { 3 - 5 } & & $\mathbf{F}_{\mathbf{1}}(\mathbf{0 . 2 \%})$ & $\mathbf{F}_{\mathbf{2}}(\mathbf{0 . 4} \%)$ & $\mathbf{F}_{\mathbf{3}}(\mathbf{0 . 6 \% )}$ \\
\hline 1. & Curcuma extract & $50.0 \mathrm{~g}$ & $50 \mathrm{~g}$ & $50 \mathrm{~g}$ \\
2. & Cornstarch & $20 \mathrm{~g}$ & $20 \mathrm{~g}$ & $20 \mathrm{~g}$ \\
3. & Aquadest & $1000 \mathrm{~mL}$ & $1000 \mathrm{~mL}$ & $1000 \mathrm{~mL}$ \\
4. & CaCl $_{2} 0,15 \mathrm{M}$ & $1000 \mathrm{~mL}$ & $1000 \mathrm{~mL}$ & $1000 \mathrm{~mL}$ \\
\hline
\end{tabular}

Table 2: The result of microencapsulation process with various sodium alginate concentrations

\begin{tabular}{lll}
\hline No. & Formula & Weight (g) \\
\hline 1 & F1 $(0.2 \%)$ & $19.86 \pm 0.11$ \\
2 & F2 $(0.4 \%)$ & $20.66 \pm 0.73$ \\
3 & F3 $(0.6 \%)$ & $21.29 \pm 0.64$ \\
\hline
\end{tabular}


Table 3: Microcapsules characterization results

\begin{tabular}{lllllll}
\hline Formula (n=6) & $\begin{array}{l}\text { Flowing } \\
\text { time (seconds) }\end{array}$ & $\begin{array}{l}\text { Statistical } \\
\text { test }\end{array}$ & $\begin{array}{l}\text { Angle of } \\
\text { repose }\left(\mathbf{2 0}^{\circ}<\boldsymbol{\infty}<\mathbf{4 0} \mathbf{0}^{\circ}\right)\end{array}$ & Statistical test & $\begin{array}{l}\text { Compressibility } \\
\text { index }(\mathbf{I} \leq \mathbf{2 0} \%)\end{array}$ & Statistical test \\
\hline F1 & $6.92 \pm 0.56$ & $\mathrm{p}<0.05$ & $27.83 \pm 0.75^{\circ}$ & $\mathrm{p}<0.05$ & $17.58 \pm 0.91 \%$ & $\mathrm{p}<0.05$ \\
$\mathrm{~F} 2$ & $7.42 \pm 0.50$ & & $32.33 \pm 1.03^{\circ}$ & & $18.25 \pm 0.61 \%$ & \\
F3 & $8.05 \pm 0.54$ & & $28.25 \pm 0.61^{\circ}$ & & $19.66 \pm 1.21 \%$ & \\
\hline
\end{tabular}
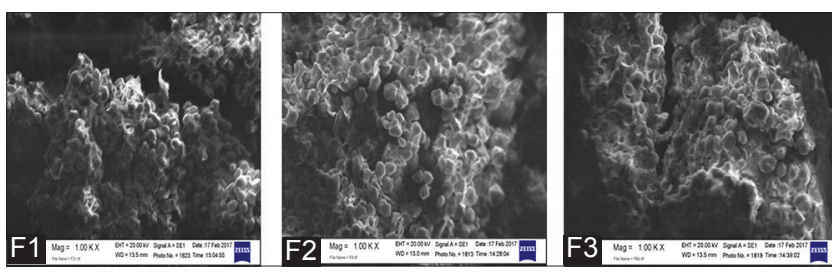

Fig. 1: Scanning electron microscope characterization of F1, F2 and F3 microcapsules

Effect of sodium alginate concentration on weight of the microcapsules

The influence of the concentration of sodium alginate to swelling and weight of the dry Curcuma extract microcapsules resulted from the microencapsulation process was shown in Table 2 .

\section{Microcapsules characterization}

Microcapsules characterization was done by flowing time, angle of repose, and compressibility index parameters. The result was shown in Table 3.

Table 3 shows the differences of microcapsules characterization from the three formulas. The flowing time of the microcapsules of F1 (0.5\%) was $6.92 \pm 0.56 \mathrm{~s}, \mathrm{~F} 2(1 \%)$ was $7.42 \pm 0.50 \mathrm{~s}$, F3 $(1.5 \%)$ was $8.05 \pm 0.54 \mathrm{~s}$. It can be concluded that the addition of sodium alginate concentration will increase the flowing time of microcapsules. The angle of repose microcapsules of $\mathrm{F} 2$ was $32.33 \pm 1.03^{\circ}$ and F3 was $28.25 \pm 0.61^{\circ}$ and F1 has $27.83 \pm 0.75^{\circ}$ of angle of repose. The compressibility index of F1 was $17.58 \pm 0.91 \%$, F2 was $18.25 \pm 0.61 \%$, and F3 was $19.66 \pm 1.21 \%$. The statistical test using one-way ANOVA methods revealed significance differences $(\mathrm{p}<0.05)$ on flowing time, angle of repose, and compressibility index between all of formula. From the results of the characterization of the microcapsules, it can be seen that the three formulas met the requirements for flowing time, angle of repose, and compressibility index, and it can be concluded that the microcapsules can be used in capsule formulation.

\section{Scanning electron microscope characterization}

Thedetermination of particlesize of Curcuma extractmicroencapsulation resulted from SWM technique is shown in Fig. 1.

It can be concluded from the figure that all of formula has similar particle size $(20 \mu \mathrm{m})$. This particle size showed that the xerogel met the requirements of microcapsules particle size $(0.2-5000 \mu \mathrm{m})$. The figure of F2 (0.4\%) showed the complete and round particle form. Meanwhile, the F1 $(0.2 \%)$ and F3 $(0.6 \%)$ showed the wrinkle particle form. This could happened because F1 $(0.2 \%)$ has low sodium alginate concentration that produced the vulnerable microcapsule. Meanwhile, the F3 $(0.6 \%)$ has high sodium alginate concentration that produced the hard microcapsule that needs the grind process to separate the granules of microcapsules. This process may cause the break of microcapsules particle.

Recent study revealed that the phenomenon above was caused by the ballooning effect. The ballooning effect is an event of bubbling of microcapsule particles as a result of the formation of water vapor in microcapsule particles. This bubble can be caused by the too high temperature of drying process or incompatibility between the microcapsule material and the condition of the appliance. When the capsule wall is not strong enough to withstand the pressure inside the microcapsule particles, the wall will break, and the particles will deflate. The ballooning effect can also cause the loss of volatile components inside [17].

\section{Organoleptic test}

The test results of the 10 panelists showed that the microcapsuled process was able to mask the bitterness taste of the Curcuma extract. The higher of the concentration of sodium alginate used, the taste become less bitter, but the odor or flavor of Curcuma extract was still aromatic of Curcuma xanthorrhizae.

\section{CONCLUSION}

Based on the analysis of the study result, it can be concluded that the raw materials of Curcuma extract can be made by SWM technique using sodium alginate isolated from brown algae, and the characterization of dry Curcuma extract microcapsule of the three formulas met the requirements of the pre-formulation tests for capsule dosage form.

\section{ACKNOWLEDGMENT}

The authors acknowledge the research supported by Rector of Universitas Muslim Nusantara Al-Washliyah. The support is under the research grant "Applied Product Research "of the year 2017 contract number 79/LP2M-UMNAW/B.07/2017.

\section{AUTHORS CONTRIBUTION}

$\begin{array}{ll}\text { Study conception } & \text { : Samran } \\ \text { Acquisition of data } & \text { : Dalimunthe } \\ \text { Analysis of data } & : \text { Samran } \\ \text { Drafting of manuscript } & : \text { Samran } \\ \text { Critical revision } & : \text { Samran }\end{array}$

\section{CONFLICTS OF INTEREST}

All author have none to declare

\section{REFERENCES}

1. Rimelda N. Isolation and Characterization of Na-Alginate from Brown Algae (Sargassum plagyophyllum (Mertens) J.G. Agardh and the Effect of the Bleaching Composition Concentration on Viscosity. A Thesis. Medan: Universitas Sumatera Utara; 2013.

2. Agoes A. Indonesia's Herbal Medicine. Jakarta Selatan: Salemba Medika; 2010. p. 15.

3. Basmal J, Yunizal J, Murtini T, Nasran S, Marsiana E, Abdulrokim I, et al. The Production of Alginate from Sargassum Seaweed. Jakarta Timur: Penebar Swadaya; 2013. p. 5, 9, 27.

4. Dalimartha S. The Prescription of Herbal Medicine for Uric Acid. Jakarta: Penebar Swadaya; 2008. p. 41-2.

5. Wilson N, Shah NP. Microencapsulation of Vitamins. ASEAN Food J 2007; $14: 1-14$

6. Biswal I, Dinda A, Das D, Si S, Chowdary KA. Encapsulation protocol for highly hydrophilic drug using non-biodegradable polymer. Int J Pharm Pharm Sci 2011;3:256-9.

7. Mikroencapsulation YS. Strategic Approach in food Fortification. Bogor: Balai Besar Penelitian dan Pengembangan Pascapanen Pertanian; 2011.

8. Yunizal Y. Extraction Technology of Alginate. Jakarta: Pusat Riset Pengolahan Produk dan Sosial Ekonomi Kelautan Dan Perikanan; 2004.

9. Budi K, Lentera Team. Brotowali: Effication and Application. Jakarta: 
Agromedia Pustaka; 2003. p. 25-9.

10. Preeti K, Jathi K. Chitosan-sodium alginate biodegradable interpenetrating polymer network (IPN) beads for delivery ofloxacin hydrochloride. Int J Pharm Pharm Sci 2010;2 Suppl 2:77-82.

11. Samran. Encapsulation and Released of Chloramphenicol from Gel of Alginat. A Thesis. Medan: Universitas Sumatera Utara Medan; 1992. p. 2-3.

12. Ansel HC. Pharmaceutical Dosage Form. Jakarta: UI Press; 2008.

13. Lachman L, Lieberman HA, Kanig Jl. Theory and practice of Pharmaceutical Industry II. $3^{\text {rd }}$ ed. Jakarta: Universitas Indonesia; 2008. p. 649-60, 886 .

14. Soekarto SP, Soewarno T. Organoleptics Evaluation for Food and Farm industry. Bogor: Pusbangtepa IPB-Press; 1981

15. Yuan Z, Fei Y, Hong C, Jie Z, Jie M, Junhong C. Alginate/graphene double-network nanocomposite hydrogel beads with low-swelling, enhanced mechanical properties, and enhanced adsorption capacity. J Mater Chem A 2016:4:10885-92.

16. Mawaddana Q. Viability Study of Microencapsulation of Lactobacillus casei by Na-Alginate Matrix. Faculty of Medicine and Health. Pharmaceutical Department. Jakarta: UIN Syarif Hidayatullah; 2015.

17. Syafi'i F. The Optimation Process of Emulsification and Encapsulation on the formulation of pepper oleoresin powder (Piper nigrum). Bogor: Institut Pertanian Bogor; 2015. p. 6, 7, 9, 10 